\title{
HIENAS DE INGLATERRA
}

\author{
Hyenae from England
}

\author{
Norma Telles*
}

\begin{abstract}
RESUMO
No presente trabalho se apresenta a imagem da hiena e se avalia sua conotação na obra de três escritoras inglesas em três momentos diferentes, sem ligação entre si. As obras sugerem reflexões e ofertam narrativas singulares.

Palavras-chave: hienas, mulheres escritoras, literatura inglesa
\end{abstract}

\begin{abstract}
This text presents the hyenae's image and its connotations in the work of three English women writers, during different moments in time and without any relation with one another. They offer us an exquisite stories and engaging thoughts.
\end{abstract}

Keywords: hyena, women writers, English literature

Ficamos entre a vida e a morte bela quando temos um nervo forte cá dentro para enfrentar a hiena da vida.

Lidia Jorge

Há muito tempo atrás, tem lá mais de cinco mil anos, os egípcios tentaram domesticar animais selvagens: a elegante gazela,

* Professora Assistente do Departamento de Antropologia na Pontifícia Universidade Católica de São Paulo (PUC-SP), entre 1978 e 2006. E-mail: ntelles@terra.com.br 
leões soberbos, como aquele que caminhava ao lado do grande faraó quando este percorria seu palácio. Por algum motivo desconhecido a tarefa foi abandonada, os animais voltaram para prados, savanas ou florestas silvestres e por lá ficaram. Foi durante esse período de achego às feras que a hiena se tornou, acreditem, uma iguaria culinária muito apreciada pelos ricos egípcios. Murmura-se até hoje que sua carne é tenra e macia. Há registros, em frisos e pinturas de grandes tumbas, do apetite egípcio por foi gras, não só de ganso como também um muito especial, o de hiena. Nas mastabas de Mereruka e Kagemni, vizires da IV dinastia (2613-2494 a.C.), esculpido em relevos nas paredes, homens à força empurram comida bico abaixo dos gansos e surpreende ver, ao lado, uma grande hiena, com as pernas amarradas, sendo alimentada do mesmo modo para a feitura do pitéu especial.

$\mathrm{Na}$ Europa as hienas desapareceram uns cinco mil anos antes de se tornarem iguaria no Antigo Egito. Sumiram do continente logo após o final da Era do Gelo, há uns dez mil anos, período durante o qual habitavam cavernas e, como toda a fauna de então, eram muito, muito grandes. Não se sabe bem porque se extinguiram no continente europeu, mas assim foi. E não restou memória de serem boa companhia ou uma iguaria. Espécimes menores ocuparam a seguir o sul da Ásia e regiões da África e lá estão até hoje, com certeza, rindo muito. Cinco tipos de hienas habitam até hoje o Planeta, há também áreas grandes reservadas a elas. As hienas-listradas, as mais famosas, vivem em bandos matriarcais e são excelentes caçadoras, sim, elas também caçam além de gostarem de carcaças e de carne apodrecida. São carnívoras como os magustos e como eles pertencem a subordem dos Feliformia (ramo dos gatos) e são primos distantes da subordem dos Caniformia (ramo dos cães), assim, a despeito de sua aparência de cão grande, são mais ligadas aos gatos. E, ao contrário de cães e gatos, a hiena sustenta o olhar se a encaramos, ela é muito, muito curiosa.

\section{Interregno}

Enganado pelas aparências, Aristóteles pensava que todas as hienas fossem machos, um inconveniente notório para a espécie! Mas, 
o que mais poderia pensar quem acreditava que a "a fêmea não contribui com sêmen para a geração", somente os homens, portanto, poderiam ser genitores da descendência? "Aristóteles forneceu à nossa tradição [Ocidental] o primeiro argumento cuidadosamente elaborado para a inferioridade feminina" (Hilman:1984:302). A visão tomista que confirma essa noção é baseada em suas afirmações. E, ainda antes dele, o divino Apolo já versejara a questão que se tornaria recorrente: "A mulher tem semente?" dúvida que é também do historiador grego Diodoro Sículo, no século I e se repete durante toda Era cristã (Hillman: idem).

No folclore grego e romano a hiena era tida como hermafrodita, portanto, uma natureza ambígua. Para Esopo, (século VI a.C.) as hienas alternavam serem machos ou fêmeas, não se sabe bem se por vontade própria ou não. Essa natureza dúbia é descrita também pelos romanos Ovídeo e Plínio (século I), e é essa noção que fará da hiena um animal de duas faces, que esconde más intenções e maldades, parte de sua natureza.

Durante a Idade Média europeia a lei proibia que hienas fossem comidas por serem

animais sujos. Então, diziam, que eram promiscuas e viviam próximas a cemitérios, pois gostavam de se alimentar de cadáveres, que desenterravam, de comer carne podre, como pode ser observado nas belas pinturas dos bestiários. Isidoro de Sevilha, em suas Etimologias, escreveu que hienas tinham uma pedra no olho que se fosse removida poderia dar à pessoa que o fizera, quando colocada em baixo de sua língua, o dom de prever o futuro. Diziam também que à noite a hiena circulava em torno de casas, gritando palavras com voz humana e quando as pessoas iam ver o que se passava, eram mortas e devoradas.

A hiena representava então uma pessoa de duas caras, não confiável; ou a humanidade que primeiro venerara o deus verdadeiro e depois os ídolos, ou ainda, uma pessoa enganadora, falsa, gananciosa e depravada. Atenção: a hiena dos fabulistas, Esopo ou La Fontaine entre outros, ou das tradições populares, fala da vida animal como metáfora para o humano, algo demasiadamente humano. Os animais medievais, por sua vez, são formas recombinadas. O filósofo Gaston Bachelard alerta contra essa noção dos animais como representantes de qualidades humanas, chamando atenção para o fato 
de a vida animal não ser simples metáfora, não conter símbolos de paixões. A animalidade para ele não é bestialidade, loucura ou perversidade, o animal é visto por suas funções, não por suas formas, "o querer viver aqui é um querer atacar" (Bachelard:1995:10) e o impulso de agressão é a energia que também impulsiona a narrativa.

\section{Hienas europeias}

$\mathrm{Na}$ Inglaterra, assim como em toda a Europa, desde o início da era moderna as hienas viveram e vivem em feiras ou zoológicos e nas figuras e noções antigas - gregas, romanas, medievais - inseridas em novos contextos. Por exemplo, na França do século XIX ela surge para nomear uma das "Monomanias", série de retratos de Théodore Gericault, como A Hiena da Salpêtrière, de 1820, ou A Monomania da Inveja. O termo monomania não é do artista, foi colocado posteriormente por alguém que pensou serem as pinturas descrições perfeitas de conceitos elaborados pelo diretor do Hospital Salpêtrière, Esquirol, que substituiu Pinel - famoso por ter libertado, por volta de 1794, os loucos de suas correntes. Esquirol, desde 1817, encomendava desenhos dos pacientes, para um livro, mas não solicitou os retratos de Gericault.

$\mathrm{O}$ diretor fazia palestras públicas e lecionava em torno de novos termos e definições para estados mentais como parte da proposta Iluminista que até hoje influencia nossa visão desse tema. A monomania era "a fixação obsessiva do enfermo sobre um único objeto". O belo quadro de Gericault mostra uma cabeça de mulher idosa, com uma touca, na qual sobressaem grandes olhos muito abertos e manchados de sangue; olhos fixos, penetrantes, em uma expressão obstinada e decidida. Um olhar obsessivo. É uma cabeça intrigante, da época em que a doença mental começou a interessar aos médicos.

A definição de monomania por Esquirol se tornou termo importante, mas logo se mostrou muito abrangente, então foram surgindo outras categorias. Na literatura, por outro lado, deixou uma marca indelével em vários livros clássicos como Crime e Castigo, de Dostoievski ou na personagem do capitão Ahab, obcecado pela baleia branca em Moby Dick de Melville; em Edgard Allan Poe e no Morro 
dos Ventos Uivantes (1847), no personagem Heathcliff, de Émily Brontë. Faltava, porém, quase meio século para começarem os grandes espetáculos das histéricas na Salpêtrière, local que era o "inferno feminino, a citta dolorosa, que confinava milhares de mulheres loucas incuráveis. Um pesadelo meio a Paris da Belle Époque" (Didi-Huberman:2003:xi).

Os estudos das enfermidades mentais, no início do século XIX, eram novidade na esfera médica e atraiam artistas que a retrataram, no caso de Goya ou Gericould, com maestria, percorrendo perfis da escuridão. Situados no lado oposto ao da racionalidade Iluminista, enxergaram outro cenário e nele mergulharam. A razão iluminista, no início do XIX, amontoava suas sombras sobre o mundo externo. "Talvez o Frankenstein, de Mary Shelley (1818) pertença também a história da psiquiatria" (Hillman:1984:126), além, claro, de ter inaugurado a moderna ficção científica, questionando a ética de se interferir na criação da vida e se tornar um livro de enorme sucesso e influência na literatura e no cinema dos séculos seguintes. "A relação entre loucura e as injustiças cometidas contra as mulheres se tornou um dos carros-chefes das ficções [a partir] do século XVIII e durante esse período os escritores descreveram a louca como vítima da tirania de parentes e pais" (Garcia:1995:50).

A monomania da Inveja, dita a Hiena da Salpêtrière, faz surgir em toda sua força uma imagem que além do folclore e das lendas, passa a integrar e interagir nas novas disciplinas do saber moderno: agora ela é, também, Hiena feroz, demarcadora de território desconhecido: o das sombras e o da desrazão.

\section{Hiena de anáguas}

Por volta de 1792, Mary Wollstonecraft (1759-1797) estava no auge de sua carreira de jornalista, escritora e filósofa política. Reconhecida não só na Inglaterra, como também internacionalmente, como escritora notável e mulher bem sucedida. Ela se preparava para atravessar o canal da Mancha e verificar in loco o desenrolar da luta na França que buscava realizar ideais que compartilhava, além de coletar material para um futuro livro sobre aqueles acontecimentos. 
O último livro que Wollstonecraft lançara refutava ideias de Edmund Burke, reconhecidamente o grande orador da época, filósofo, em sua critica a Revolução e condenação ao livro do Reverendo Price - grande amigo de Mary - que expusera ideias radicais em um livro por ela elogiado em uma resenha que fizera pouco antes. Burke defendia que a tradição fosse respeitada, o governo apoiado; acima de tudo demonstrava suspeita em relação a mudanças que deveriam acontecer lentamente. Essas ideias, lembra Gordon, eram anátema para Mary.

Anos antes ela havia se tornado admiradora de Burke, quando ele apoiara a Revolução Americana e agora, ao vê-lo professar preceitos opostos, ficou indignada. E, logo, num impulso, pegou da pena e escreveu uma refutação às ideias de Bruke. "Sua refutação seria direta e verdadeira, decidiu, apresentando tópicos conforme ocorriam a ela [...], em linguagem de conversação [...] Ela se permitiu usar a emoção para atacar o texto dele com fervor romântico" (Gordon:2015:150).

Wollstonecraft considerava que nenhuma causa razoável era isenta de emoção e durante toda sua vida buscou integrar razão e sentimento, em seus textos e em sua vida. Se o sentimentalismo resultava em descaminhos, em escrita fraca, pensava Wollstonecraft, o mesmo acontecia com a razão árida. Disto decorreu seu esforço vida a fora, com mais ou menos sucesso, para combinar razão e sentimento. Mary foi sempre uma apaixonada por ideias e pelas pessoas em sua vida.

Wollstonecraft terminou logo sua refutação à Burke - $A$ Vindication of the Rights of Men - e em vinte e oito dias as livrarias já o disponibilizavam. Os leitores imediatamente percebiam que o título por ela escolhido fazia referência as declarações dos revolucionários franceses, um ano antes, Declaração dos direitos do Homem e do Cidadão, clara evidência de seu apoio a causa. O livro recebeu críticas favoráveis na primeira tiragem publicada anonimamente. $\mathrm{O}$ sucesso levou seu editor e ela a decidirem fazer a segunda tiragem com o nome da autora. Desastre, os críticos mudaram de tom, fizeram-se severos ao constatar a autoria feminina; o livro se tornou de uma hora para outra "incoerente e absurdo, cheio de erros". Uma das críticas mais ferozes se tornou um anátema público e uma sentença notória repetida por séculos: 
"Mary é uma hiena de anáguas"

escreveu o historiador da arte ultra conservador Horacio Walpole, conde de Orford, filho caçula de um Primeiro Ministro inglês, à sua amiga Hannah More. Walpole apoiava as ideias e elogiava o livro de Burke, detestava a Revolução Francesa. Então, ele ataca não só a mulher como escritora, mas também suas ideias das quais discorda com fervor. Para outra amiga, Lady Ossory, em janeiro de 1793, quando soube da decapitação de Luiz XVI, enviou carta onde dizia não ter palavras para descrever o que estava sentindo, para ele era quase o fim do mundo. Até então "selvagens, bárbaros, \& companhia, eram termos para os pobres e ignorantes índios ou negros ou hienas" Observa-se então que hiena para ele é uma categoria de pessoa marginal, colocada, na hierarquia social, abaixo de todos os outros ditos marginais, à margem das margens da sociedade. Em caso de ser mulher era dita, além de desclassificada, prostituta.

E assim Mary, que ele também chamava de serpente venenosa, representando a mui maligna Eva, mãe de todos nós, é usada para reafirmar o primado de Adão, o privilégio dos homens brancos e o papel secundário e derivado de mulheres e todos os Outros indivíduos. Mary tinha a força e o impulso agressivo que a levava em frente em suas empreitadas, profissionais ou amorosas e se manifestava na força de seus argumentos e suas narrativas. As condutas agressivas e as estórias cruéis "são funções de ataque, princípios dinamizadores" (Bachelard:145). E então, tornando-se notória como hiena de anáguas, viu sua fama crescer.

Houve críticos ainda mais cruéis, mas o livro continuou tendo apreciadores e no final foi bem sucedido. "Mary estava preparada para esses ataques. Ela sabia que se aventurara em território tabu. Após os elogios da primeira tiragem sua coragem aumentara e ela estava pronta para sustentar suas ideias" (Gordon:2015:153).

Ao contrário dos críticos que em geral tinham educação formal, primorosa no caso de Walpole, Mary era autodidata, uma mulher culta e instruída, com ideias próprias a respeito do mundo. Uma mulher que em sua vida seguia as ideias que propagava, trabalhava horas a fio lendo e escrevendo e viveu de sua própria pena.

O livro contestando Burke não foi o primeiro de Wollstonecraft. Há anos fazia resenhas para uma revista de prestígio e escrevera Thoughts on the Education of Daughters: with reflections 
on Female Conduct, in the more importante duties of Life, um livro muito interessante, diferente dos comuns manuais de boas maneiras para moças. O título longo indicava que queria ser levada a sério, que escrevia para advertir e afirmar seus direitos como ser racional. Interessante notar que foi a partir da observação de sua própria vida, da de suas irmãs e amigas que Wollstonecraft tornou geral a observação pessoal, um modo de raciocínio que segue em outros momentos e outros argumentos: ela observa um fato singular, pessoal ou não, observa mais casos, os argumentos que sustentam uma ideia e logo extrai uma regra geral.

No caso do livro sobre a educação das filhas sugere noções muito originais, assim como original era sua voz: emprega linguagem coloquial para expressar seu descontentamento com a situação que trata, indaga: "Quem é a mulher ideal? Seria ela uma donzela desfalecida, facilmente cansada e ingênua? Não! Ela e um ser humano inteligente e cheio de recursos" (apud Gordon:2015:89). Ela observou que as opções para as mulheres solteiras sem dinheiro eram poucas, alertava-se sobre prostituição, eram avisos de precaução sobre um destino melancólico, triste e pobre. Outra ocupação aceita para as mulheres era se tornarem governantas o que não lhe parecia uma solução feliz. No século XIX, Charlotte Brontë que como suas irmãs e como Mary Wollstonescraft teve experiência nesta ocupação, dizia que ser governanta era uma escravidão - sentença com a qual Mary concordaria se ainda vivesse - todos ignoravam a governanta, passavam por ela sem ver, e seus deveres se avolumavam sem parar, escreveu Brontë em uma carta.

Era preciso educar as moças, não cansou de repetir Wollstonecraft, para terem profissões respeitáveis que lhes permitissem sobreviver de modo independente. Ninguém falava assim, na época, ninguém pensava em tais coisas, mesmo mulheres que tomavam parte na vida pública; muitas continuavam pensando as moças como muito 'delicadas' para se tornarem independentes dos homens. Mary achava essas ideias intoleráveis, entendia que o principal objetivo da vida de todos e de qualquer um deveria ser a liberdade.

Antes de embarcar para Paris, ela vestiu suas anáguas e, mais uma vez em um impulso, seguindo seu rápido raciocínio, Wollstonecraft escreveu mais um livro, este fadado a se tornar um 
marco na filosofia política. Vindications of the Rights of Woman foi entregue às livrarias em janeiro de 1792 ,

Mary acerta o centro da cena, sua voz é clara e forte. Ela é engraçada, rápida e inflamada - como deve ter sido em pessoa - mas também rigorosamente lógica, dando aos Direitos da Mulher a perspicácia virtuosa de um diálogo socrático $[\ldots]$ da primeira à última página exalta a liberdade da mulher que deveria interessar a todas as pessoas (Gordon:2015:170).

Porque, argumentava, as condições ultrajantes de ignorância e falta de liberdade na qual as mulheres eram mantidas não eram boas para ninguém, o mundo ficaria melhor se as mulheres tivessem direitos. A sua voz, porém, era na Inglaterra uma voz solitária, na França, por outro lado, conheceria várias mulheres que se pronunciavam e eram até bem mais radicais do que ela. Olympe de Gourges foi uma delas e também outras se aproximavam de suas ideias, como Mme Roland de quem Mary se tornou amiga. Mas muitas, incluindo as duas mencionadas aqui, que acabaram sendo presas ou perdendo literalmente suas cabeças quando uma reviravolta nos poderes e ideias da Revolução levou-as à guilhotina ou a prisões e abafou o movimento feminista nascente.

A maioria das mulheres não tinha conhecimento algum a respeito do mundo. Pior, acostumadas com afirmações de inferioridade partilhavam dessas ideias e pensavam ser a fragilidade um trunfo. A ideia que ser delicada tornava a mulher mais atraente era digna de riso para Wollstonecraft, ela discordava inteiramente. Em Vindications critica o Rousseau que pensa que as mulheres não precisam de educação igual a dos homens ou de liberdade. Mary indaga: por que as mulheres tem que agradar os homens? Ela pensava que o progresso exigia mudanças dramáticas em ambos os sexos e em suas relações. Ao criticar Rousseau, a hiena de anágua perdeu apoiadores liberais; para os conservadores era já uma causa perdida.

Woolf pensa que o conflito entre todas as contradições que viveu marcam o rosto de Mary, "tão resoluto, mas sonhador, tão sensual, mas inteligente e além do mais tão bonito [...] a vida de uma 
mulher como essa estava fadada a ser tempestuosa" (Woolf:2014:313).

Mary Woolstonescraft escreveu outros livros entre os quais Letters Written during a Short Residence in Denmark, Norway and Sweden [Cartas escritas durante uma curta Risidência na Dinamarca, Noruega e Suécia]. Literatura de viagem era até então prerrogativa dos homens, Mary conhecia bem esses livros porque fizera resenha de vários deles, até mesmo antes de ir para Paris e, depois de sua viagem, tinha confiança sobre a maneira como escreveria, relatando suas peripécias e os cenários que visitara. É um livro reflexivo, mistura de livro de viagens, cartas, memoirs, observações. É uma viagem psicológica tanto quanto uma viagem física e é mais um livro inovador. Ela antecipa ideias sobre a natureza semelhantes às do poeta Wordsworth, seus comentários são pertinentes e instigantes.

E escreveu alguns romances que não obtiveram o mesmo sucesso, um deles, deixou inacabado, Maria, or the Wrongs of Women (1791), contempla e descreve uma nova forma de opressão em sua época, um novo modo de lidar com o estranhamento ou com fantasmagorias, muito apto a imobilizar as mulheres:

Moradias de horror tem sido descritas, assim como castelos, cheios de espectros e quimeras, invocados por formulas mágicas de gênios (...) Mas, formados da mesma matéria da qual são feitos os sonhos, o que são elas perto da mansão do desespero, a um canto da qual Maria se sentava, esforçandose por relembrar seus pensamentos dispersos! (Wollstonecraft:1994:7)

Assim começa a narrativa através da qual o leitor fica conhecendo Maria, pela voz de um narrador em terceira pessoa. A jovem personagem está sentada, confusa, a um canto de um quarto. Ao reordenar os pensamentos, ainda sem saber bem aonde se encontrava, Maria descortina a paisagem através de uma pequena janela engradada: avista uma extensão de azul acinzentado sobre um trecho de jardim desolado e parte de edifícios que, percebe, haviam ficado abandonados por muito tempo. Decadentes, passaram "por reparos desajeitados, meramente para deixá-los habitáveis (Wollstonecraft:1994:9)". Custa a perceber que está presa em um hospício - as novas moradias de horror - onde a internara o marido 
por motivos muito duvidosos. O romance é também político, pois expõe a instituição legal do casamento na qual as esposas se tornavam propriedade do marido, podiam ser reduzidas, até injustamente, à condição de prisioneiras, alerta, como prisioneiras eram as ocupantes da Bastilha - como aquela que se tornaria conhecida como a Hiena da Salpêtrière no século XIX - isto é, vitimas sofredoras de tirania arbitrária.

"Ao fim e ao cabo, Mary Wollstonecraft nos parecerá, suspeito, como uma das grandes prosadoras da língua [inglesa] e uma das poucas de quem pode ser dito que se tivesse vivido mais, teria dado importantes contribuições literárias, talvez ao romance", escreveu Ellen Moers (1977:145).

Wollstonecraft foi uma profissional competente sempre cônscia do que queria realizar como escritora, "impaciente com restrições queria quebrar regras, estilística e tematicamente. Do mesmo modo viveu sua curta e turbulenta vida, derrubando tradições e seguindo seu próprio caminho" (Gordon:2015:493). Morreu por complicações no parto aos 36 anos, depois de dar a luz uma filha, Mary como ela - que se tornaria Mary Shelley - e como ela seria genial e rebelde; uma filha que cresceu seguindo as ideias da mãe e viveu independente como escritora.

Mary Wollstonecraft, a hiena de anáguas,

cujo sentido da própria existência era tão intenso, que mesmo em seu tormento clamou, não consigo pensar em não ser mais - em me perder - não, parece-me impossível que eu cesse de existir', [...] Sem dúvida uma forma de imortalidade lhe pertence, ela está viva e ativa, ela argumenta e experimenta, nós escutamos sua voz e traçamos sua influência mesmo agora entre os vivos" (Woolf:1932).

\section{Hiena no sótão}

O casamento de Jane Eyre e de Edward Fairfax Rochester foi interrompido quando à pergunta retórica "se alguém sabe de algum impedimento, fale agora, ou para sempre se cale", três homens entraram capela a dentro, gritando sim!, eles se opunham por um bom motivo: o noivo era casado e a esposa vivia ali perto. Paralisia geral, 
afinal revela-se o que Jane intuíra, Rochester tinha segredos. Jane, que mal conseguia emitir um murmúrio ou uma exclamação, foi possuída pela imediata certeza que o homem por quem se apaixonara não era ele, era outro que não existia mais. Rochester admitiu sua falta. Então, todos voltaram para a mansão e,

"Subimos a primeira escada, atravessamos a galeria, seguimos para o terceiro andar; uma porta baixa e negra, aberta pela chave mestra do sr Rochester, admitiu-nos em um quarto com tapeçarias, uma grande cama e um armário" (p.264)". Nessa ante câmera a luz das velas tornavam fantasmagóricas as figuras dos doze apóstolos no topo de folhas que formavam a porta do armário e "o móvel adquire vida própria querendo saltar da página" (Lutz:2017:18). Rochester se dirige ao homens que se manifestara contra seu casamento na capela, lembrando-lhe que fora naquele cômodo que ela o mordera e esfaqueara. Jane não entendeu, a quem se referiam? não sabia a quem, nem ao que. Continuou calada. O sr Rochester então levantou uma tapeçaria da parede embaixo da qual havia outra porta que abriu com sua chave e passaram todos para um quarto pequeno, sem janelas, onde ardia um bom fogo protegido por alta e forte grade. Do teto, presa por uma corrente, pendia uma lamparina.

Grace Pole tomava conta do fogo, talvez cozinhasse alguma coisa. No canto mais sombrio do aposento Jane acabou por perceber uma figura que corria de um lado para o outro.

"O que era aquilo, se fera ou ser humano, não se podia dizer à primeira vista: rastejava, parecia andar de quatro; agarrava-se e rosnava como um estranho animal selvagem: mas, estava coberto com roupas e uma cabeleira escura e grisalha, rebelde como uma juba, cobria sua cabeça e seu rosto" (p.264).

O sr Rochester mal indagara de Grace como haviam passado o dia, quando ouviram um grito medonho: traseiras".

"a hiena vestida levantou-se e postou-se em pé nas patas

O jogo linguístico cessa quando o grito, com sua raiva gratuita, mostra "um cogito sonoro e energético: eu grito, portanto sou uma energia" (Bachelard: 1995:112). O grito primeiro está na garganta, depois é ouvido, ele não imita nada, é pessoal, ele exulta, é 
a pessoa gritada. O grito inarticulado, "simples e único, atesta a vitória da força". E ela ataca.

As luzes bruxuleantes no quarto deixaram entrever uma figura assustadora, parecia cada vez maior e não ficava nada a dever a sua contrapartida francesa, a Hiena da Salpêtrière. Podia-se até constatar ser ela mais feroz e agitada do que sua congênere, embora, como ela, tivesse marcada em sua fisionomia e figura os traços da enfermidade que a acometia. Bertha Mason, pois esse era o nome da esposa do sr Rochester, dita a Hiena, que agora contemplavam, estava trancada em um quarto sem janelas há dez anos! como não enlouquecer? Mulher aprisionada e isolada, perdida nas sombras, as palavras sem resposta lhe sumiram entre as brumas. Imagem da dor e do desespero; uma fera ferida, murmurando, miando, rosnando, gargalhando como uma hiena.

A loucura, porém, não lhe tirara a força, bem ao contrário, olhos vermelhos, continuava agressiva, viril e perigosa. A hiena do sótão ainda passava por breves períodos de consciência durante os quais agia com equilíbrio. Era esperta o bastante para conseguir algumas vezes roubar a chave do seu quarto, enganando Grace, e fazer incursões fantasmagóricas pela casa, como, por exemplo, quando tentou incendiar a cama onde dormia Rochester, que não notou nada e só se salvou pela intervenção de Jane que sentindo o cheiro da fumaça, o resgatou.

A guardiã se afasta do fogo, aflita, pede ao senhor que saia logo para evitar ocorrências desagradáveis, a fera era astuta, diz ela, poderia machucá-lo mesmo não tendo uma faca. Jane contempla a Fera, até então oculta no sótão, sem dúvida dona daquelas risadas estranhas e arrepiantes que várias vezes escutara e lhe diziam ser de outra pessoa. A hiena imediatamente pulou em cima e agarrou Rochester pela garganta, entrando em luta corporal com ele que só se defendia, não queria machucá-la!... Conseguiu enfim, prender-lhe os braços, sentá-la em uma cadeira e amarrá-la com cordas, sempre com o devido cuidado, claro, para não feri-la... E ali, enfim, confrontaramse Jane Eyre, Bertha Mazon, a Hiena e, entre elas um elo, o sr Rochester que foi primeiro a narrar suas desventuras.

Ele se volta para seus acompanhantes e, irônico, com um sorriso cáustico e desolado, apresenta: "Esta é minha esposa, o único abraço conjugal que jamais conheci -“ e voltando-se para Jane, 
continua "E esta é a que eu desejava ter, essa jovem, em pé aqui, tão grave e quieta à porta do Inferno" (p.265, itálicos no original). Frente a frente as duas se mostram bem diferentes: a esposa mantida presa, alta, morena, rica e fera e Jane Eyre, também aprisionada no mesmo enredo, comum, clara, pequena, órfã e pobre - esta sua condição, pobre, estava prestes a mudar - iria herdar de um tio - mas ela ainda não sabia.

Rochester continuou seu longo relato: como um segundo filho não herdaria nada do pai, mas este que não pensaria nunca em dividir as propriedades, também não queria ver o filho caçula pobre, por isso lhe arranjou um bom casamento, com a filha de proprietários de terras na Jamaica, que lhe traria um belo dote. Possuído pelo desejo pela bela créole, e precisando do dinheiro, Rochester se deixou levar e foi arrasado pelos enganos, engodos e mentiras, não só da moça como também de sua família. Tornou-se insuportável viver com ela, repete ele, pois dizia grosserias sem parar e ao mesmo tempo era "intempestiva e não casta", o que acabou por lhe provocar aversão. Declarada insana pelos médicos de seu torrão natal, pouco depois, ela foi levada para a Inglaterra, onde ele acreditava seriam melhores as condições para tratá-la, e colocada no quarto sem janelas de Thornfield. Wollstonecraft escrevera: "moradias de horror tem sido descritas..." outras ainda restaram a descrever.

Depois de esposá-la Rochester ficou sabendo que sua esposa pertencia a uma família de loucos, idiotas, maníacos por três gerações. A mãe de Berta, "a mestiça", era louca e bêbada e "ensinara bem a filha" conta ele, que logo lhe seguira os passos. O marido viveu então em profundo pesar e vergonha.

A loucura, no século XIX, no caso das mulheres, era associada a paixão sexual, a fatos corporais e a emoções que, lembra Showalter, Jane admitia sentir também. Nesta cena do sótão são descritas as possibilidades para a sexualidade das mulheres da época: moças solteiras não deviam suspeitar serem sensuais, esposas não deviam sentir emoção ou prazer no sexo, isso era reservado às mulheres livres que circulam pela sociedade, do grand-mond passando pelos teatros e cabarés até às periferias das cidades.

Pelas leis inglesas Rochester não precisava devolver o dote da esposa, por outro lado, não havia possibilidade de se separar ou se divorciar dela. Sendo assim, com um pecúlio necessário para 
prosseguir sua vida nômade, com seus hábitos "de sultão", como comenta Jane consigo mesma quando o observa com amigos, seguiu em frente, viajou muito. O lado mais sombrio da troca, a loucura e a sexualidade da mulher que lhe provocava aversão e vergonha pública, ou a aversão e a vergonha que provocaram a insanidade, ele trancou no sótão. Nada, porém, o impediu de ter outros casos com mulheres livres, que se aproveitavam do dinheiro dele, como ele se aproveitara do da esposa louca. Essas ligações eram breves, logo o entediavam, ou elas o traiam, coisas facilmente resolvidas a peso de ouro.

Interessante notar que ao contrário de Jane Eyre que aprendia com suas vivências e das hienas, que hoje sabemos pelos estudiosos, aprendem com suas experiências, Rochester não aprendia com o seu próprio viver e se repete. Tendo cuidado da esposa, isto é, tendo ocultado a mulher que o envergonhava e constrangia, prosseguiu, com o mesmo tipo de relações e encontros. Por Jane se apaixonara e não queria, melhor dizendo, não admitia a hipótese ou pensava ser possível ser abandonado por ela. Ainda acreditava que sua vontade deveria prevalecer, fosse a respeito do que fosse.

Escutamos o longo relato do sr Rochester, conhecemos a vida de Jane Eyre, pelos relatos no que antecedem, no conto, a cena do sótão, mas pouco sabemos sobre Bertha Mazon. Ela é comparada ao espectro alemão do vampiro, a um demônio, um cão louco, uma Messalina indiana e uma feiticeira, além, claro, de Hiena. Para Charlotte Brontë, a autora desse inesquecível conto maravilhoso, a palavra hiena além de lascívia, talvez falsidade, indica, ao que parece, uma boa paixão, pois quando em Bruxelas a autora se apaixonou por um certo professor, um homem casado e com filhos, em cartas e anotações chama-o de 'cisne negro', em referencia a sua mente poderosa e temperamento colérico e irritável. Também para ele usa as expressões 'gato louco' e 'hiena delirante' que transpõe para a cena do sótão em Jane Eyre.

Entenda-se então que para uma amante dos animais como foi Charlotte Brontë, e todo clã Brontë, esses termos não eram necessariamente derrogatórios, ao contrário, podiam ser carinhosos, constata Lutz (2017:149). O que aproxima Jane e Bertha são emoções conflitantes, medo, cólera, carinho, apreço. Algumas críticas pensam que Brontë não gostava de Bertha, o que acredito não ser o caso, ela construiu uma personagem inesquecível, forte, enigmática, central em 
suas ações para o desenrolar da trama. E embora apareça em poucas páginas, não é só por agir de modo que Jane gostaria de agir que ela é marcante, é por estar na situação de aprisionamento, a qual Jane conhecia bem, e mesmo não tendo palavras para dizer a maldição de seu viver, ela a expressava. E teve forças e tino suficiente para destruir todos os traços de poder patriarcal e opressor que a mantiveram presa tanto tempo.

Brontë ao descrever Bherta Mazon alude a desenvolvimentos da psiquiatria vitoriana e atribui o comportamento dela a "loucura moral". No século XVIII a insanidade significava desarranjo da razão, mas no XIX isso muda. Em 1835, a psicologia passa a ser baseada na noção de "loucura moral", considerada uma perversão mórbida dos sentimentos e inclinações naturais sem nenhuma desordem específica ou defeito do intelecto (Showalter:1977:120). As mulheres eram tidas como mais susceptíveis a esses desarranjos e podiam herdá-lo; o apetite sexual era considerado um dos principais sintomas no caso das mulheres e aquela que fosse acometida por essa loucura moral "ficava sujeita a severas sanções e era vista como abnormal ou patológica”.

Rochester contrapõe Bertha e Jane e se apresenta como uma vítima do pai, do irmão e das intrigas da família Mazon. Ele é a ligação entre as duas, cada qual culpada a seu modo em seu relato por lhe infligir dor ou vergonha. Uma por excessos, a outra porque se recusou a eles, não quer ser sua amante, o que o deixou inconformado e o faz perceber o abandono como vitimização, portanto acaba também vítima de Jane, a moça em busca de auto realização e de uma vida própria.

$\mathrm{Na}$ manhã seguinte ao encontro no sótão Jane acorda e compreende que está em seu pequeno quarto, como sempre, mas "onde estava a Jane Eyre do dia anterior? e sua vida?" (p266). A última entrevista dos dois, depois do encontro no sótão, foi uma agonia, ele fez de tudo para evocar os sentimentos e a simpatia dela, jogou com a vulnerabilidade de Jane. Ele a deseja como amante, ela também o deseja, mas, não cedeu, percebeu a tentativa de manipulação, a arrogância dele, o que a fez encontrar de novo sua força a agir por si mesma e para si mesma. Então, sem avisar, sem dizer nada, ela partiu, foi embora sem dinheiro, sem futuro, sem planos, uma "pequena figura de mulher pobre, obscura e comum, arriscando exposição aos elementos, ostracismo e inanição" 
(Rich:1973:102). Inanição, exposição aos elementos e ostracismo ela os teve em boa dose e ele nunca a encontrou.

"Leitor, casei-me com ele!" começa assim o último capítulo do livro. A ausência de Jane da mansão durara mais de um ano, ela passara por muitas dificuldades, quase morrera de fome, sede e frio sem ter onde morar, mas conseguira aos poucos refazer a vida. Recusou se casar com outro homem sem amor e assumir o ideal missioneiro dele. Ela não esquecia nunca seus próprios ideais e sua lealdade era para com eles. E, pasme leitor! Jane passou a não precisar se preocupar com sua sobrevivência cotidiana porque recebeu de seu tio Eyre, que vivia na Madeira, uma herança significativa. Só então escutou Thornfeild chamando-a de volta.

Quando se encontrou novamente com o sr Rochester, não eram mais desiguais, não estavam nos seus papeis anteriores de senhor e empregada, nem Rochester habitava mais o mundo 'do sultão' que havia sido o seu. Estava ferido, ficara cego e perdera uma mão durante a tentativa de salvar Bertha Mazon do incêndio que ela iniciara na mansão. $\mathrm{O}$ fogo destruiu tudo, ela morrera e ele ficara debilitado. Agora com Jane, viveram isolados e felizes. O livro termina dez anos depois do reencontro, Jane comenta, "estarmos juntos é para nós sermos ao mesmo tempo tão livres quanto na solidão, e tão alegres quanto em companhia. Conversamos, o dia todo...." (p.404)

Charlotte Brontë (1816-1885) publicou Jane Eyre em 1847, foi seu primeiro livro a ser impresso e estava fadado a um longo sucesso que chega até nossos dias. Publicou-o sob o pseudônimo de Currer Bell, mas edições seguintes traziam na capa o nome da autora. Ao mesmo tempo em que foi bem sucedido, o livro chocou alguns grupos Vitorianos, não só pela carga sexual entre os personagens principais, mas especialmente pela cólera nele contida.

Matthew Arnold, famoso crítico, notou em 1853 que Charlotte Brontë só "pensava em fome, rebelião e raiva" (apud G\&G:1972:337), resposta típica daqueles que se sentiam ultrajados pelo tema e conteúdo da história. Podemos hoje entender os termos dessa crítica como positivos: ela sempre pensava em rebelião, fome em todos os sentidos e em transformar a cólera de modos que Bertha não conseguira. A publicação recebeu críticas favoráveis, e, um 
pouco mais tarde, até a Rainha Vitória leu o "intensamente interessante romance" para "o querido Alberto" (Bentley:1969:93).

A escritora escocesa Mrs Oliphant, em 1855, observou sagazmente que até então os romances seguiam um mesmo roteiro: os amantes eram humildes e devotados e o único amor que valia a pena era o galante e formal. Então, sem aviso, continua ela, Jane Eyre roubou a cena e a revolução mais alarmante dos tempos modernos se seguiu a esta invasão. Jane Eyre roubou a cena pela estrutura diferente do romance, por ser uma narrativa experimental, por modificar o tema do amor e a relação que mulheres e homens mantinham com ele e com a vida, enfim, por mostrar que uma mulher comum, pequena e pobre poderia desejar e conseguir ter uma vida própria.

\section{Breves comentários do século XX e seguinte}

Em 1966, a escritora Jean Rhys re-escreveu a história de Bertha Mazon a partir do ponto de vista da louca do sótão. É o relato da vida de uma rica créole, Antoinia, da Jamaica, obrigada a se casar com um inglês que não recebe um nome no romance, ele aqui não tem patronímico, não tem existência própria. Nessa versão, porém, a moça também enlouquece. O livro, Vastos mares de Sargaço foi grande sucesso e uma primeira entrada para diferentes pontos de vista étnicos a partir de Jane Eyre; inaugurou uma vertente de estudos de crítica literária feminina a partir de outros espaços e pontos de vista, discutindo questões que no século XIX eram mal entrevistas.

Gilbert e Guber, no final dos anos 1970, publicaram um estudo profundo e marcante para a crítica literária feminista. Nele o livro de Brontë é trazido para o centro da cena e recebe uma nova leitura onde assinalam a extensão da cólera contida na trama. Jane Eyre tornou-se uma figura mais conhecida, uma figura maior, "emblema da rebeldia apaixonada, mal disfarçada" (Gilbert e Gubar:1979:337), o exemplo da mulher que anseia escapar da sala de estar e das mansões patriarcais em uma trama de aprisionamentos e fugas. As autoras ponderam que os obstáculos enfrentados por Jane Eyre são os mesmos que qualquer mulher em sociedades patriarcais precisa superar: "opressão, fome, loucura, frieza" (Gilbert e 
Gubar:1979:339). As autoras lembram que o sobrenome de Jane, expõe ire, ira em inglês, portanto ela exibe de certo modo o que vai dentro de si e assim consideram o tema da cólera reprimida, contra a sociedade, contra todos os opressores, como cerne do romance.

Notam Gilbert e Gubar que desde que chegou a Thornfield, o local predileto de Jane era o sótão e o telhado por onde passeava, cenário para os discernimentos mais importantes para a personagem. E embora Jane tenha pressentido o predador, os corredores escuros do sótão lhe parecem como "os do castelo do Barba-Azul", ela nunca desconfiou que havia uma mulher aprisionada tão perto dela. Predador e presas estavam por perto, numa situação bem mais complexa do que em simples oposição. Ao tomar conhecimento da louca no sótão, da hiena raivosa e forte, o que acontece de mais assustador é a percepção que Bertha é mais um avatar de Jane (Gilbert e Gubar:1979:359). Ela age como Jane gostaria de agir, corta o véu de noiva e acaba provocando o incêndio que destrói toda aquela arquitetura, a casa, suas emoções, suas memórias; Bertha morre vitoriosa no terraço do sótão, enquanto Rochester fica cego e aleijado ao tentar salvá-la. "Bertha, em outras palavras, é o mais verdadeiro e mais sombrio duplo de Jane: ela é o aspecto colérico da órfã, o feroz eu secreto que Jane sempre tenta reprimir" (Gilbert e Gubar:1979:360).

Deixar entrever a raiva reprimida pode parecer paralelo a sugerir sexualidade reprimida, porém, o paralelo não é válido porque a raiva, consideram, é muito mais perigosa para a ordem da sociedade (Gilbert e Gubar:1972:338). Os dois aspectos, sexualidade reprimida, latente e raiva reprimida contra disposições da sociedade e situações de humilhação, marcam o texto de Brontë. A análise de Gilbert e Gubar é ousada, controversa e uma leitura obrigatória. É persuasiva e como o livro de Brontê, foi propulsora de críticas literárias e feministas se tornando catalizadora de estudos acadêmicos e literários.

Em 1981, bell hooks inicia a corrente de estudos de mulheres negras, indagando se também não é uma mulher. Suas ideias têm feito longa carreira não só entre os movimentos negros, como também para a crítica literária em geral. Gloria Jean Watkins é uma acadêmica, escritora e ativista influente que escolheu para si o pseudônimo bell hooks. Seu artigo "Olhar oposicional: espectadoras negras" é leitura 
fundamental. A autora questiona a partir de textos e atenta observação o que a "dominação patriarcal significa para negras/os que estão constantemente sendo olhadas/os, dissecadas/os, consumidas/os; e o que significaria para negras/os realmente olharem para trás" (Perry:2017:513). O seu Black Looks se tornou um clássico para que as teorias feministas literárias passassem também ao enfoque racial.

Em 1985 Gayatri Spivak publicou um texto polêmico onde descreve Bertha Mazon como um produto axiomático do Imperialismo, fazendo objeção ao papel dela ser o duplo de Jane e nada mais; seu papel na narrativa, parece-lhe, corretamente, mais complexo. É um texto provocante que recebeu diferentes respostas, provocou debates e abriu outro canal de pesquisas e proposições, o dos estudos pós-coloniais. Cenários imperiais ou cenários raciais criaram diferentes campos estéticos contestatórios até os dias atuais. Essas e outras divergências na crítica literária trouxeram para os estudos fatores inexplorados que desafiaram imagens recorrentes a partir do livro de Brontë, pois ao investigar a opressão a escritora abriu caminho para estudo de outras opressões. Diferenças modelaram a vida de Bertha e Jane, ambas, no entanto, são parte da sociedade patriarcal, racista e imperialista do século XIX, então devem ter algo em comum além de Rochester.

Diferenças não são divisões e a diversidade necessariamente não cria barreiras, mas respostas alternativas. "Locais de opressão separados - por exemplo, gênero, raça, classe, etnia, sexualidade cada vez mais são reconhecidos como sistemas inter-relacionados de opressão" (Russell:2019:133).

Depois vieram os anos 1990 com outros questionamentos a partir de outras derivações, depois os anos 2000 com outras perspectivas, e depois e depois... outras ainda que no futuro vão surgir.

Ao fim e a cabo, ainda percebemos que Charlotte Brontë tem um estilo arrebatador, mantém controle total de sua narrativa,

A personalidade feminina que constrói é completa e se expressa através de inúmeros expedientes narrativos, tais como, 'desenvolvimentos psicológicos e dramas interiores são representados em sonhos alucinações, visões, pinturas surreais, toques ate surrealistas, e mascaradas; as experiências sexuais do corpo feminino 
são expressas espacialmente através de elaboradas e rítmicas imagens recorrentes de salas e casas (Showalter:1977:113)

Nos anos futuros, Jane Eyre, de Charlotte Brontë, ainda será lido e relido. A poeta Adrianne Rich lembra que entre vários romances que nos dão versões contraditórias do que é ser uma mulher, "Jane Eyre tem para nós uma força especial e um valor de sobrevivência" (Rich:1984:89), pois continua transmitindo à poeta, e a nós leitores, o sentido de conter, através e além da força da imaginação criativa da autora, alguma nutrição que ainda necessitamos.

\section{Hiena no jantar dançante}

Leonora Carrington (1917-2011) narra em conto breve, de 1939, as peripécias de uma debutante:

$\mathrm{Na}$ época em que fui debutante, costumava ir amiúde ao zoológico. Ia com tanta frequência, que conhecia melhor os animais do que as moças de minha idade. Era porque queria fugir do mundo que ia diariamente ao zoológico. $\mathrm{O}$ animal que cheguei a conhecer melhor foi uma jovem hiena. Ela também me conhecia. Era muito inteligente. Ensinei-lhe a falar francês e, em troca, ela me ensinou sua linguagem. Assim, passávamos muitas horas agradáveis (p.35).

Nota breve e contemporânea: estudiosos observaram que as hienas possuem um repertório vocal dos mais ricos dentre os mamíferos terrestres, incluindo primatas. O riso é apenas uma das inúmeras manifestações, talvez a mais conhecida, usada ao que parece para identificar os membros de seu grupo social. Outras existem como o grito jovial que significa "estou aqui" ou a ladainha de murmúrios, que os estudiosos consideram comovente, entre a mãe e sua prole. A hiena, ressaltam, é uma boa mãe.

Mas, com toda certeza, as hienas não são capazes de falar inglês ou aprender francês como no conto de Carrington com o qual prosseguimos:

A mãe da jovem amiga da hiena havia organizado um baile para apresentá-la à sociedade. E, por causa disso, ela chorara noites 
inteiras, não gostava de bailes, achava-os extremamente aborrecidos $\mathrm{e}$, mais ainda, se fossem festas em sua honra!

$\mathrm{Na}$ véspera do evento a debutante relutante contou seu infortúnio para a amiga hiena que não entendeu a razão de tantas lágrimas, pois, se fosse ela, ficaria encantada em ir a um baile. A jovem, então, tem uma ideia: "vestida com minhas roupas, você poderia muito bem ocupar meu lugar", diz à hiena. Esta, porém, retruca: não nos parecemos o suficiente, senão iria com o maior prazer. Não! diz a jovem, não há problema, a festa é à noite, as luzes são fracas e, com algum disfarce, ninguém irá notá-la em meio a multidão. A hiena aceita, entusiasmada. A debutante relutante abre a jaula da hiena e rapidamente as duas fogem, tomam um táxi e chegam até a mansão já iluminada para os convivas.

Refugiam-se no quarto da moça. A mãe entra - a intrusa se esconde - e indaga: "de onde vem esse mau cheiro tão forte, filha?" E sem esperar resposta, sai rápido, depois de recomendar que, por favor, tomasse um bom banho antes de se vestir. É a hiena, porém, quem coloca o belo vestido de noite, para ela um bom banho não adiantaria. $\mathrm{O}$ vestido ficava grande e os sapatos de salto alto a incomodavam. A moça lhe empresta um par de luvas velhas para esconder os pelos das mãos. Olhando-se no espelho, vaidosa, a hiena percebe que se as luvas cobriam os pelos das mãos, o rosto não se prestava a disfarces.

Dúvidas sobre o que fazer, horas a fio de discussões, quando a hiena tem uma ideia: indaga se há uma serviçal na casa e diante de resposta afirmativa, diz que poderia devorá-la e usar seu rosto. A moça concorda com o plano, com a condição que a face só seja arrancada depois da morte da servente. Tudo bem, diz a hiena, "para mim tanto faz". A jovem então chama Marie, a criada, que de imediato é morta e devorada pela hiena, rapidamente desaparecem todas as carnes e todos os ossos. Depois de se fartar, enfastiada, a hiena guarda os pés da morta e os põe em uma bolsa para comer mais tarde. Recorta e coloca o rosto dela sobre o seu, como uma máscara, "se admira diante do espelho" e pronto, desce para a festa.

A jovem amiga da hiena recomenda-lhe que não fique muito perto de sua mãe, pois esta poderia sentir o cheiro e perceber que não era a filha. De resto, não conhecia ninguém, então a hiena não deveria ter problemas. E lá vai ela, enquanto a moça, cansada das emoções do 
dia, senta-se junto à janela para ler As Viagens de Gulliver, de Jonathan Swift.

Coincidência: este era um livro muito apreciado por Jane Eyre menina, no conto de Brontë. Jane entendia as peripécias da história como "narrativas de fatos", o que lhe parecia atraente após ter concluído, por observação das folhas verdes do jardim, e de flores como a dedaleira, que fadas e duendes tinham se retirado da Inglaterra para lugares mais selvagens e acolhedores. Jane acreditava que um dia poderia empreender uma longa viagem e encontrar os minúsculos campos, as minúsculas casas e pessoas de Lilipute. Após o episódio do quarto vermelho - o castigo e as visões de terror passou a ver o livro de modo totalmente diferente. Parecia-lhe mesmo outro livro, sinistro e lúgubre, enquanto Gulliver lhe surgia como alguém tristíssimo, viajando por regiões muito perigosas (Brontë:1983:21).

A jovem que lê As aventuras de Gulliver na Inglaterra das primeiras décadas do século $\mathrm{XX}$, a personagem sem nome de Carrignton, porém, apenas aprecia a história, comentários, se os tem, guarda para si mesma. Noto que este é um clássico da veia literária satírica inglesa, gênero com o qual Carrington está trabalhando no conto A Debutante, com pinceladas de humor negro. Depois de uma hora e tanto de leitura, ela percebe um mau presságio, "um morcego entra pela janela dando gritinhos", e como sente muito medo de morcegos, ela se esconde atrás da cadeira.

Ainda está com o livro entre as mãos, quando sua mãe, pálida de fúria, entra em seu quarto, reclamando que mal os convidados haviam se sentado à mesa "o ser que ocupou seu lugar" se levantou e gritou: "Com que então, meu cheiro é um pouco forte, não é? Pois, não como pastéis" e, dizendo isso, arrancou o rosto e comeu-o! Em seguida, deu "um grande salto e desapareceu pela janela" (Carrington:1992:35-40).

O que é identidade? A aparência e as vestes, como alguns personagens do conto entendem? O interior, mas qual é ele se somente as aparências parecem ser levadas em conta? O cheiro? Para os surrealistas - grupo que Carrington frequentou - ao serem liberados de suas aparências, propriedades físicas e funções, os objetos e os seres adquirem um inesgotável poder de migração. Instaura-se uma atmosfera de indeterminação e certeza que evoca um tempo primal, 
quando as coisas não conheciam estados definitivos, quando não havia oposições nem contrários (Moraes:2002:76). Um corpo subversivo envolve noções de superfície e limites borrados entre interior e exterior.

A pele que separa o fora e o dentro também não é suficiente para definir a identidade. A pele é viva, "um estado de agitação", movimentos; a pele é "transitória e mutável como as montanhas, as pedras e as cavernas" (Laurentiis:2017:47). O dentro e o fora, a escultura e o corpo são indissociáveis. Transferências, troca de papéis, fronteiras fluídas entre espécies, híbridos de todo tipo, metamorfoses urgentes e diretas, os vários reinos da natureza, criam personagens fantásticos em contos não menos fantásticos. "A importância de definir superfícies, o medo da invasão, a perda da brecha, o desejo de ser penetrada, a fusão, são modos diferentes do questionamento ontológico central a respeito do lugar do sujeito no espaço" (Cottenet-Hage:1993:82).

Os contos de Carrington não são somente ficcionais, algumas também são históricas e fundem as várias fontes. Os textos ou pinturas são sempre múltiplos em sugestões, caminhos, ambivalências, tornando impossível qualquer fixação. Ela procura reconstruir o mundo de modo a permitir que as mulheres se encarreguem de si próprias e se abram para trocas com o exterior em busca intencional de independência.

Há outra hiena próxima a Carrington em seu autorretrato de 1938, The Inn of the Dawn Horse (O Albergue do Cavalo da Aurora), hoje parte da coleção do Metropolitan Museum de Nova Iorque. No quadro a figura central tem os traços da artista, se encontra em um quarto ou sala, um tanto misterioso, sem móveis, exceto por uma poltrona vitoriana na qual ela está sentada e mal acomodada. Quem está ali, porém, não é uma menina e sim uma mulher. Uma de suas mãos aponta para uma hiena com três tetas cheias de leite, enquanto a outra permanece suspensa sobre o braço da poltrona que, estranhamente, mimetiza o gesto da mão. Atrás, pendendo da parede, um cavalo de pau, brinquedo de criança, com sua sombra e, através da janela aberta, se avista um corcel branco galopando pela paisagem noturna.

O cavalo branco - recorrente na obra de Carrington - salta para a noite, impulso e poder no imaginário da artista, manifestos já 
no cavalo de brinquedo que não é estático porque tem suporte para balançar e pode ter sugerido à criança um impulso inicial. Agora que já cresceu, o brinquedo se torna recordação sombreada na parede. A hiena é selvagem e estranha, suas inúmeras conotações também a dizem cruel. No quadro, é protetora da moça, um familiar no dizer de Warner (2017), poderosa e nutriente. A cadeira em que a jovem está sentada no quadro é metamórfica, seus pés se transformam em pés femininos, seus braços se misturam com os da mulher. Ela usa botinas vitorianas, calças e casaco de montaria, mas não está confortável na poltrona. Uma mulher não deveria se sentar na borda da cadeira com as pernas abertas, como a do autorretrato, observa Guiral (2018:101). No mais, a vasta cabeleira, meio juba meio crina de cavalo, embaraçada e ao vento, como a juba da hiena do sótão, Bertha Mason, afirma ser a figura uma mulher.

No retrato de Carrington, ela olha a hiena e pressente o corcel que corre janela a fora. O cavalinho de pau deixado de lado, é também um sacrifício do cavalo. Opera-se, assim, uma alternância de significados, pois se nos mitos ou nas praças o cavalo é montaria de heróis, conquistadores, imperadores e salvadores (Hilmam (1997). No quadro de Carrigton o que lemos é a gentileza, independência, impulso animal, movimentos. O mistério do animal só pode ser percebido quando o sacrifício do cavalo o livra do peso heroico e marcial, peso esse que não se vê na pintura. Livre do fardo cultural mais óbvio, o animal pode sugerir, por exemplo, Epona, a antiga deusa celta, ou o sentido que lhe dava a alquimia que atribuía ao ventre do cavalo a função de calor interno para a digestão de eventos, de incubação.

A hiena do quadro exibe três tetas repletas de leite o que permite entrever a fusão entre criatividade biológica e artística e a necessidade de retroceder até épocas anteriores à linguagem para retomar a força e a ligação entre os reinos da natureza, entre a vida e a morte. Animal da noite, a hiena é transformadora de matéria, devora a carne, limpa e mastiga ossos com seus poderosos dentes, mordisca os resíduos da existência anterior, infantil e socializada. No quadro a hiena, é feroz pelo olhar, mas mansa ao se aproximar da moça sentada, de quem parece estar cuidando. Torna-se uma mãe selvagem, rica em nutrição e sugestões; o cavalo branco é mágico, como os dos contos celtas de sua infância e dispara, em seu galope, voa livre pela 
noite assim como a hiena pula pela janela livre das grades do zoo, rumo as sombras e a noite no conto da debutante relutante/decidida.

As metamorfoses por serem imediatas trazem maior leveza e agilidade aos movimentos. Alberth aproxima essas duas cenas da noção de abjeção em Kristeva. Nos dois casos, essa seria também a função da hiena, mostrar a raiva e o ressentimento da artista pelo fato de tentarem colocá-la no mercado do casamento. Abjeção é termo empregado para a hiena, porém, no conto e no quadro ela não evoca qualquer suposta sujeira; aponta sim para a perturbação da identidade, do sistema e da ordem, daquilo que não respeita fronteiras, posições e regras (Alberth:2004:35). Warner, por outro lado, lembra que Carrington é gótica em seu humor e que o horror se volta para "a experiência real e perseverante" no que "traz à mente Mary Shelley, que também fantasiava coisas improváveis e conseguiu assim sobreviver ao Romantismo" (Warner:2017:xiv) - e que por seu lado evoca a mãe de Shelley, a hiena de anáguas, Mary Wollstonecraft.

Bachelard lembra que é possível ultrapassar formas humanas para tomar posse de outros psiquismos, e que é preciso perceber o animal em suas funções, não em suas formas. "A vida animalizada é a marca de uma riqueza e de uma mobilidade dos impulsos subjetivos" E ainda, "é o excesso do querer viver que deforma os seres e que determina suas metamorfoses" (Bachelard:1995:12). No conto ou no quadro de Carrington o que se mostra é o impulso muscular, a violência realizada na mesma certeza do gesto animal e esse, para Bachelard, é o segredo da poesia ardente. $O$ gosto pelas metamorfoses, diz o filósofo, caminha ao lado a pluralidade de atos.

Nos contos, pinturas, peças de teatro, e outras intervenções de Carrington, animais e humanos dialogam. Jovens rebeldes são amigas de hienas, de cavalos e de mulheres-lobas. Ela escolheu como fera a hiena e o cavalo como animal de predileção. Em 1987, em uma entrevista para o documentário The Flowering of the Crone, Carrington revelou ter escolhido a hiena porque nos zoológicos que frequentara desde pequena, sempre fora particularmente atraída por elas, considerando que a grande virtude desses animais era comerem o lixo - as hienas são animais da limpeza em seus ambientes, as vezes também em outros, e elas sempre sentem fome.

Em 1999, numa entrevista concedida em sua própria casa, ela explica melhor a ideia: "Sou como uma hiena, entro em latas de lixo. 
Tenho uma curiosidade insaciável" (Alberth:2004:32). Sou como uma hiena curiosa, sempre remexendo o lixo! Ali se pode encontrar alguma coisa que ao se misturar com outra gera novas funções, novas metamorfoses e formas. Nessa comparação surreal a identificação parece chocante, mas o choque é parte do humor negro característico de Carrington.

O choque faz parte também do conto da debutante relutante/decidida, no qual a jovem personagem não hesita em concordar com a morte do Outro, um ato de violência predatória deliberada que se torna, na narrativa, vínculo irônico para dois motivos de contestação social: um em relação à classe alta inglesa e seus rituais formais centrados em festas, nas aparências e maneiras codificadas, e outro, mais sutil, aponta a perversa amizade através da qual a hiena age no papel de procuradora da jovem, do mesmo modo que a hiena do sótão agiu como substituta de Jane Eyre, ou que a injúria "hiena de anáguas" perversamente deu novo impulso e projeção à pensadora Mary Wollstonecraft. Em todos os casos a risada da hiena tornou mais leve o choque das novas mudanças, confrontações e metamorfoses, ao mesmo tempo em que foi ampliando nossos conhecimentos e imagens sobre um animal que não nos é próximo.

Foi em torno da presença da hiena na literatura moderna da Inglaterra, a partir do século XVII, que desenvolvi este trabalho. Central foi a noção de Bachelard (1995) dos animais como seres que figuram, encarnam "energias habitadas" ou "síntese de atos", para que desenvolvesse aqui uma leitura reflexiva, em aberto, sobre obras literárias singulares. Mostrou-se o que vai além de uma simples representação literária, pois produz multiplicidades no limite do visível que a linguagem coloca em cena em um espetáculo vivo. As artes "assim como as demais esferas da sociedade, estão constituídas, em maior ou menor grau, pelos regimes de verdade como as desigualdades de gênero, tendo em vista que pertencem ao campo da cultura, com suas tensões e historicidade" (Tvardovskas:2013:81). 


\section{Referências}

ALBERTH, Susan. Leonora Carrington, Surrealism, Alchemy and Art. Burlington: Lund Humphries, 2004.

BACHELARD, G. Lautreamont. Paris: Jose Corti, 1995. bell hooks. Ain't I a woman? New York:South End Press, 1981.

BENTLEY, P. The Brontës. London Thames and Hudson, 1986.

BRONTË, C. Jane Eyre.London: Collins's Clear-Type Press, 1848, $3^{\mathrm{a}}$ ed.

Jane Eyre. Rio de Janeiro: Francisco Alves, trad. Marcos Santarrita, 1983.

CARRINGTON, 1. La casa de Miedo. Madrid:Siglo Veintiuno, trad. Francisco Torres Olivier, 1992.

COTTENET-HAGE. "The Body Subversive: corporeal imagenery in Carrington, Prassinos and Mansour" in CAW, M e alii Surrealism and Women. Cambridge: MIT Press, 1993.

FEDERICO, A.F. The Madwoman in the Attic, After Thirty Years. Columbia: University of Missouri Press, 2009.

GARCIA, C.C. Ovelhas na Névoa. Rio de Janeiro: Ed. Rosa dos Tempos, 1995.

GILBERT, $S$ e GUBAR, $S$ The Madwoman in the Attic.New Heaven: Yale University Press, 1979.

GORDON, C. Romantic Outlaws. New York: Random House, 2015.

GUIRAL, J.C. Hechiceras. Espanha: Ediciones Trea, 2018.

HILMANN, J. O Mito da Análise. SP: Paz e Terra, 1984.

e alii Dream Animals. Vancouver: Chronicle Books, 1997.

LAURENTIIS, G B D Louise Bourgeois e modos feministas de criar. São Paulo:2017.

LUTZ, D. El gabinete de las hermanas Brontë. Madrid: Siruela, trad. Maria Porras Sánchez, 2017. 
MASCORT, M. "Mastabas" in National Geographic, Historia. Barcelona: $n^{\circ}$ 167, 01/2018.

MOERS, E. Literary Women. New York: Oxford University Press, 1977.

MORAES, E.R. O corpo impossível. São Paulo: Iluminuras, 2002.

MUNDY, J. (ed.). Surrealism, desire unbound. London: Tate, 2002.

PERRY, K-K Y. "O olhar oposicional de bell hooks no Brasil: tradução e pensamento feminista negro diaspórico" in Brandão I, Cavalcanti I, Lima Costa C, A. Lima, AC, Traduções da Cultura (orgs). Editora Mulheres, 2017, pp.510-518.

RICH, A. On Lies, Secrets and Silence. London: Virago, 1984.

ROSEMONT, P. Surrealist Women: an International Anthology. Austin: University of Texas Press.

SHOWALTER, E. A literature of their Own. Princenton: Princenton Un. Press, 1977.

SPIVAK, G.C. "Three Women's Texts and a Critique of Imperialism" in Critical Inquiry 12, (Autumn), 1985.

TOMALIN, C. Life and death of Mary Wollstonecraft. London: Pinguin, 1985.

TVARDOVSKAS, L. Dramatização dos corpos. São Paulo: Intermeios, 2013.

WARNER, M. "Introduction" in L.Carrington, Down Below. New York: nyrb, vii-xxxvii, 2017.

WOLLSTONECRAFT, M. Maria, of the wrongs of woman. London and New York:1994.

Reinvindicação dos Diretos das Mulheres.

São Paulo: Boitempo, trad. Ivania Pocinho Motta, 2016.

A Vindication of the Rights of Woman.

USA, Pearson, 2006.

RECEBIDO EM: 01/06/2018 APROVADO EM: 12/07/2018 
